\title{
Neuromedin B and Gastrin-Releasing Peptide mRNAs Are Differentially Distributed in the Rat Nervous System
}

\author{
Etsuko Wada, ${ }^{1}$ James Way, ${ }^{1}$ Anne Marie Lebacq-Verheyden, ${ }^{2}$ and James F. Battey ${ }^{1}$ \\ 'Laboratory of Neurochemistry, National Institute of Neurological Disorders and Stroke, National Institutes of Health, \\ Bethesda, Maryland 20892, and ${ }^{2}$ Cellular Genetics Unit, Institute of Cellular and Molecular Pathology, University of \\ Louvain, B1200 Brussels, Belgium
}

\begin{abstract}
The bombesin-like peptides are a family of structurally related amidated peptide ligands that are known to have a variety of potent pharmacological actions on various cells, including neurons in the rat brain. Two mammalian representatives of the bombesin family of peptides have been identified, gastrin-releasing peptide (GRP) and neuromedin $B$ (NMB). Previously, we cloned the rat preproGRP gene and determined the locations of neurons expressing this gene using in situ hybridization. In this study, we describe the structure and sequence of the rat preproNMB gene, and the first detailed cellular localization of preproNMB mRNA in rat brain using in situ hybridization. Nucleotide sequence analysis of CDNA and genomic clones reveals a 117 amino acid precursor whose overall structure is similar to that described for human preproNMB. Sequence similarity between the rat NMB and GRP genes is observed only over a limited 10 amino acid sequence encoding the carboxy termini of the GRP and NMB peptides, the region shown to be necessary and sufficient for high-affinity receptor binding. In situ hybridization studies performed with cRNA probes specific for NMB or GRP mRNA show that the distribution of cells expressing either mRNA in brain is very distinct. NMB mRNA is found most prominently in the olfactory bulb, dentate gyrus, and dorsal root ganglion. In contrast, the highest levels of GRP mRNA are observed in the forebrain (isocortex and hippocampal formation). This heterogeneity of MRNA distribution for these peptides suggests that these 2 structurally related peptides may have very distinct functions as neuropeptides in the rat nervous system.
\end{abstract}

Bombesin is an amidated tetradecapeptide originally isolated from the skin of the European frog Bombina bombina (Anastasi et al., 1971) with potent bioactivity in the mammalian nervous system (for reviews, see Taché and Brown, 1982, and Spindel, 1986). Many bombesin-like peptides, sharing amino acid similarity at the carboxy terminal receptor-binding domain of the peptide, have subsequently been purified, and have been divided into 3 families, based on the amino acid sequences of the carboxyl terminus (Spindel, 1986; Erspamer et al., 1988). Mam-

\footnotetext{
Received Nov. 14, 1989; revised Mar. 13, 1990; accepted Apr. 5, 1990.

We wish to thank Drs. Yoshinobu Hara, Ben Szaro, and Harold Gainer for their critical comments on the manuscript.

Correspondence should be addressed to Etsuko Wada, Laboratory of Neurochemistry, NIH Building 36, Room 4D20, 9000 Rockville Pike, Bethesda, MD 20892.

Copyright (C) 1990 Society for Neuroscience $0270-6474 / 90 / 092917-14 \$ 03.00 / 0$
}

malian representatives for 2 of the families have been identified; they are gastrin-releasing peptide (GRP) and neuromedin B (NMB), isolated originally from porcine gastric tissue (McDonald et al., 1979) and spinal cord (Minamino et al., 1983) respectively. GRP, like the amphibian peptide bombesin, has a leucine residue at the penultimate position, while NMB, like ranatensin and litorin, has phenylalanine as the penultimate residue (Fig. 1). No mammalian representative of the third family, the phyllolitorins, has been definitively identified as yet.

Radioimmunoassay and immunohistochemical analyses have indicated a wide distribution of both GRP-like and NMB-likc immunoreactivity in the mammalian CNS (Panula et al., 1982, 1983, 1984; Roth et al., 1982; Minamino et al., 1984; Chronwall et al., 1985; Namba et al., 1985a,b; Moody et al., 1986; Steel et al., 1988). However, the cross-reactivities of the antisera used for these and other structurally related peptides was difficult to exclude rigorously in most of these studies. Many of the ambiguities in these earlier studies can be clarified using in situ hybridization histochemistry with very sensitive and specific cRNA probes derived from isolated cDNA clones. Using these methods, it should be possible to make an unambiguous comparison of the precise locations in the brain where GRP and NMB gene products are expressed. Comprehensive and precise mapping is an important first step in determining the individual functional contributions of these 2 structurally related mammalian bombesin-like peptides, since several peptides from the bombesin family, including GRP and NMB, have been reported to bind at high affinity to bombesin receptors characterized on Swiss 3T3 cells (Zachary and Rozengurt, 1985, 1987), a rat pituitary cell line (Westendorf and Schonbrunn, 1983), and rat brain bombesin binding sites (Moody et al., 1986).

We previously reported the isolation and characterization of rat preproGRP cDNA and genomic clones (Lebacq-Verheyden et al., 1988), which were used to generate cRNA probes for localization of neurons expressing preproGRP mRNA in rat brain (Zoeller et al., 1989). To allow direct and unambiguous comparison of the distribution of GRP and NMB gene products in the rat nervous system, we isolated and characterized both cDNA and genomic clones for the rat preproNMB gene. Recently, Krane et al. (1988) reported the isolation and characterization of cDNA clones encoding human preproNMB. In this paper, we report the complete structure and nucleotide sequence of the rat preproNMB gene. Genomic and cDNA clones provided the probes needed for the first detailed localization of NMB-expressing neurons in the rat nervous system using in situ hybridization, allowing a direct comparison of regions expressing GRP mRNA and NMB mRNA. 


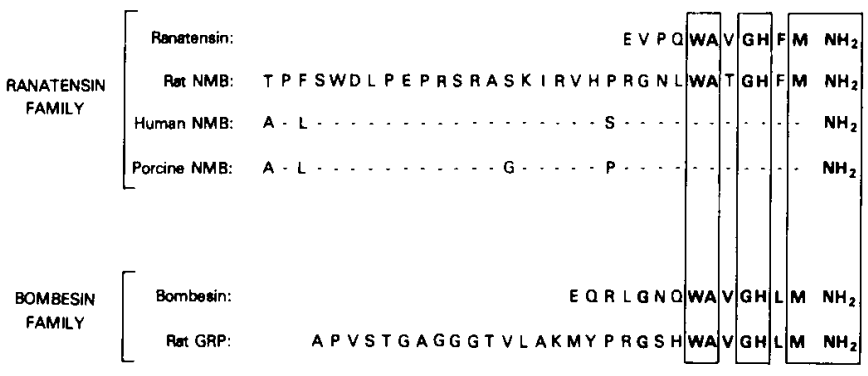

Figure 1. Amino acid sequence comparison of mammalian bombesinlike peptides with their amphibian counterparts. The 2 families of the bombesin-like peptides (ranatensin and bombesin) are shown as separate blocks, with the amino acid sequence of the amphibian founder peptide at the top of each block. The amino acid sequence of rat NMB and GRP is shown below the sequence of the amphibian homologs. The sequence of human (Krane et al., 1988) and porcine (Minamino et al., 1985) NMB peptides is also shown for comparison, with conserved residues indicated by dashes and differences with the rat sequence (at residues $1,3,15$, and 21 ) indicated. Conserved amino acids within the carboxy terminal region that structurally and functionally define this group of peptides are boxed; amino acid residues conserved within the ranatensin and bombesin family are printed in bold letters. The $\mathrm{NH}_{2}$ designation at the carboxy termini of the peptides indicates that they are $\alpha$-amidated.

\section{Materials and Methods}

Genomic cloning of rat preproNMB. A 180 base segment from the human preproNMB gene was obtained by amplification using polymerase chain reaction (Mullis et al., 1986). Two gene-specific synthetic oligonucleotide primers (5' primer: CCGCGGCCCGGGCACAGCC; $3^{\prime}$ primer: CGGTGGCCCAGAGGTTGCC) whose sequence was based on the structure of a human NMB cDNA clone (Krane et al., 1988) were used to prime DNA synthesis on human placental genomic DNA template using buffer and cycling conditions recommended in the GeneAmp kit (Perkin-Elmer Cetus). The amplified segment was sequenced to verify its identity and used as a probe to screen a genomic library prepared from Sprague-Dawley rat genomic DNA cloned into the Eco RI site of Charon 4A. One million bacteriophage clones were screened after transfer to nitrocellulose filters using standard techniques (Davis et al., 1986). The filters were hybridized overnight at $37^{\circ} \mathrm{C}$ in hybridization buffer (40\% formamide, $5 \times$ SSC, $20 \mathrm{~mm}$ Tris, $\mathrm{pH} \mathrm{7.4,1} \times$ Denhardt's, 20 $\mathrm{mg} / \mathrm{ml}$ denatured salmon sperm DNA, $10 \%$ dextran sulfate), and washed 3 times at room temperature in $2 \times$ SSC, $0.1 \%$ SDS, followed by 2 washes at $48^{\circ} \mathrm{C}$ in $0.1 \times$ SSC, $0.1 \%$ SDS. Nine positive plaques were purified for analysis. A 350 base Pst I-Pst I fragment that hybridized to the NMB-specific probe was identified and subcloned into $\mathrm{m} 13 \mathrm{vec}-$ tors for dideoxy-chain termination sequencing (Sanger et al., 1977) using a modification of the original technique (Davis et al., 1986).

Isolation of a rat preproNMB $c D N A$ clone. A near full-length rat brain NMB cDNA clone was isolated by polymerase chain reaction amplification using a previously described method (Frohman et al., 1988). Rat brain cDNA was prepared from $10 \mu \mathrm{g}$ mRNA by reverse transcription using a (dT) $)_{17}$-adaptor (5' GACTCGAGTCGACATGGATTTTTTTTTTTTTTTTT $3^{\prime}$ ) as the primer. The specific cDNA segment from the rat NMB gene was amplified from the cDNA template using a $3^{\prime}$ primer ( $5^{\prime}$ GACTCGAGTCGACATGGA $3^{\prime}$ ) and a gene-specific primer corresponding to sequences from exon 1 of the rat preproNMB gene (5' GAAAACCCGTTTGGCACAGC 3'). Initially, $100 \mathrm{ng}$ of the genespecific primer was annealed to the $50 \mathrm{ng} \mathrm{cDNA}$ template at $60^{\circ} \mathrm{C}$ for 2 min in the buffer recommended for Taq DNA polymerase amplification by the manufacturer (Perkin-Elmer Cetus). Second-strand cDNA synthesis proceeded at $72^{\circ} \mathrm{C}$ for 20 min using 5 units of Taq DNA polymerase. The double-stranded cDNA fragment was amplitied by 40 cycles $\left(94^{\circ} \mathrm{C}, 30 \mathrm{sec} ; 60^{\circ} \mathrm{C}, 2 \mathrm{~min} ; 72^{\circ} \mathrm{C}, 3 \mathrm{~min}\right)$ of polymerase chain reaction using a Perkin-Elmer DNA Thermal Cycler and 100 ng each of $3^{\prime}$ primer and the gene-specific primer. A 650 base fragment was isolated from a polyacrylamide gel by electroelution, polished and kinased with T4 DNA polymerase and polynucleotide kinase, subcloned into $\mathrm{m} 13 \mathrm{mp} 10$ vector, and sequenced by the dideoxy-chain termination technique using standard methods (Davis et al., 1986). The near full- length NMB cDNA fragment was used to map exons 2 and 3 in the genomic clone. These regions, along with $5^{\prime}$ flanking sequences, were also subcloned and sequenced.

SI nuclease protection assay. S1 nuclease protection assays were performed using uniformly labeled single-stranded probes essentially as described (Davis et al., 1986; Lebacq-Verheyden et al., 1988, 1989). The Eco RI-Bam HI fragment containing exon 1 of rat NMB was subcloned into $\mathrm{m} 13 \mathrm{mp} 18$. A single-stranded probe complementary to the $5^{\prime}$ end of NMB mRNA was prepared by extending a synthetic oligonucleotide primer (complementary to bases 767-784; Fig. 1) with the Klenow fragment of DNA polymerase after the primer was annealed to $\mathrm{ml} 3$ subclone template, incorporating ${ }^{32} \mathrm{P}$-dATP during the synthesis reaction. The probe was truncated by digestion with Eco RI, followed by denaturation and gel electrophoresis. The 780 base single-stranded probe covering the $5^{\prime}$ end of NMB mRNA was identified by autoradiography of the gel, excised, and electroeluted. About 100,000 cpm of the probe (specific activity about $500 \mathrm{cpm} / \mathrm{pg}$ ) was hybridized to $20 \mu \mathrm{g}$ poly A + RNA from rat brain, duodenum, and fibroblasts (Rat-1 cultured cells), as well as to yeast tRNA. Hybridization reactions were performed in $50 \mu 1$ of $70 \%$ formamide, $400 \mathrm{~mm} \mathrm{NaCl}, 20 \mathrm{~mm}$ Tris, $\mathrm{pH}$ $7.4,1 \mathrm{~mm}$ EDTA. The samples were heated to $80^{\circ} \mathrm{C}$ for $2 \mathrm{~min}$, and hybridized overnight at $50^{\circ} \mathrm{C}$. Samples were diluted to $400 \mu \mathrm{l}$ with 300 mм NaCl, 30 mm sodium acelate, $\mathrm{pH} \mathrm{4.5,3} \mathrm{mм} \mathrm{ZnCl}_{2}$, and digested with S1 nuclease (400 units; Boehringer Mannheim) at $37^{\circ} \mathrm{C}$ for $2 \mathrm{hr}$. $\mathrm{S} 1$ protected probe segments were analyzed by electrophoresis on a $5 \%$ denaturing polyacrylamide gel. The precise localization of the $5^{\prime}$ end of the protecting mRNA was determined by co-electrophoresis of dideoxy sequencing samples prepared using the $\mathrm{m} 13$ subclone as template and the same synthetic oligonucleotide primer as was used to prepare the probe.

RNA blot analysis. Poly A+ mRNA was isolated from rat tissues by homogenization in $4 \mathrm{M}$ guanidine thiocyanate, centrifugation through cesium chloride, and oligo dT chromatography as described (Davis et al., 1986). Ten micrograms of oligo dT sclcctcd RNA from each sample were resolved on $1 \%$ formaldehyde agarose gels and transferred to a nitrocellulose filter by capillary blotting. The blot was hybridized with a denatured ${ }^{32} \mathrm{P}$-labeled nick-translated NMB cDNA probe (about $500,000 \mathrm{cpm} / \mathrm{ml}$ in $40 \%$ formamide, $5 \times \mathrm{SSC}, 20 \mathrm{~mm}$ Tris, $\mathrm{pH} 7.4,1$ $\times$ Denhardt's, $20 \mu \mathrm{g} / \mathrm{ml}$ denatured salmon sperm DNA, and $10 \%$ dextran sulfate) overnight at $42^{\circ} \mathrm{C}$, and washed twice at room temperature in $2 \times \mathrm{SSC}, 0.1 \% \mathrm{SDS}$, followed by 2 stringent washes at $60^{\circ} \mathrm{C}$ in 0.1 $\times$ SSC, $0.1 \%$ SDS. After washing, the filters were exposed for several days to detect hybridizing species.

Genomic DNA blot analysis. Fifteen micrograms of rat genomic DNA were digested with either Eco RI or Bam $\mathrm{HI}$, resolved by electrophoresis on an $0.8 \%$ agarose gel, and transferred to nitrocellulose. The filters were hybridized and washed in the manner described for RNA blot analysis. The 2 probes used were a 350 base pair Pst I-Pst I exon 1 fragment from the genomic clone and a 650 base pair cDNA fragment, which were labeled by nick translation or random priming to specific activities of $100-500 \mathrm{cpm} / \mathrm{pg}$.

In situ hybridization analysis. Two ${ }^{35} \mathrm{~S}-$ labeled antisense NMB cRNA probes (about $1000 \mathrm{cpm} / \mathrm{pg}$ ) were prepared by in vitro transcription by either Sp6 or T7 RNA polymerase using procedures described previously (Zoeller et al., 1989). The 2 antisense NMB probes were transcribed from a Pst I-Pst I NMB exon 1-containing fragment template subcloned from a genomic clone or a near full-length CDNA template. The rat GRP antisense cRNA probe was transcribed under identical conditions from a full-length GR.P cDNA clone template (Zoeller et al., 1989). Negative control probes were sense-strand transcripts from each of the 3 antisense cRNA probes, which showed no hybridization signal above background in all cascs. The preparation of tissue sections, prehybridization, hybridization, and autoradiography were performed using previously established methods (Wada et al., 1989). Mounted rat brain sections $(25 \mu \mathrm{m})$ and other tissue sections $(15 \mu \mathrm{m})$ were treated with proteinase $\mathrm{K}\left(10 \mu \mathrm{g} / \mathrm{ml}, 37^{\circ} \mathrm{C}\right.$, for $\left.30 \mathrm{~min}\right)$, acetylated, and dehydrated. ${ }^{35}$ S-labeled cRNA probes $\left(5-10 \times 10^{6} \mathrm{cpm} / \mathrm{ml}\right)$ in hybridization buffer were applied to the slides and incubated at $55^{\circ} \mathrm{C}$ overnight. The slides were treated with RNase A $\left(20 \mu \mathrm{g} / \mathrm{ml}, 37^{\circ} \mathrm{C}\right.$, for $\left.30 \mathrm{~min}\right)$ to reduce nonspecific background, washed in progressively lower concentrations of SSC (beginning with $2 \times$ SSC and ending with $0.5 \times$ SSC) at room temperature, and washed at high stringency in $0.1 \times \mathrm{SSC}$ at $55^{\circ} \mathrm{C}$ for $30 \mathrm{~min}$. The slides were dehydrated and exposed to Beta Max film (Amersham) or Cronex film (DuPont) for $3 \mathrm{~d}$ to 2 weeks. The slides were dipped in Kodak nuclear emulsion NTB3 (diluted 1:1 with distilled 


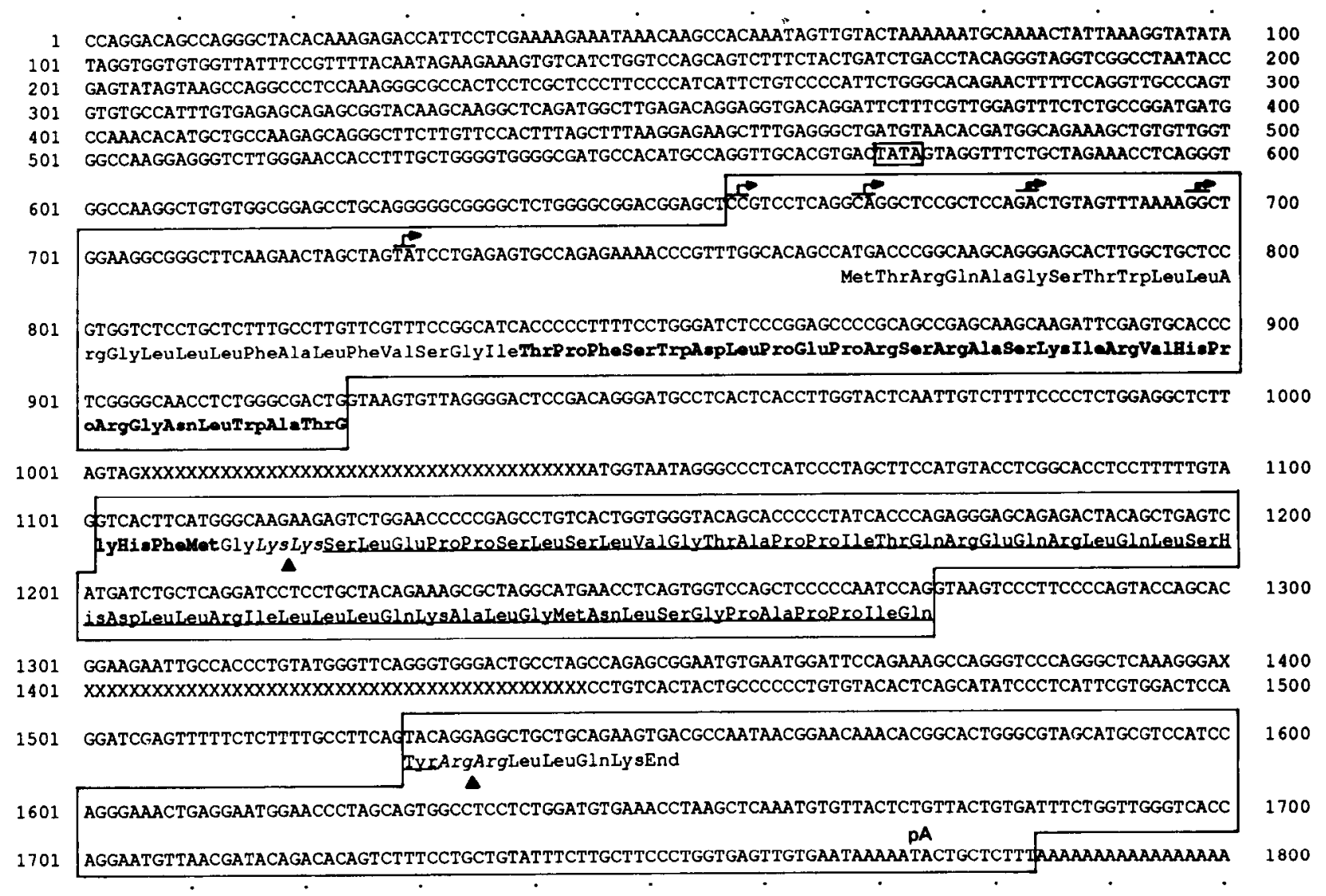

Figure 2. Structure and nucleotide sequence of the rat preproNMB gene and cDNA. The 3 exon structure (exons are boxed) and nucleotide sequence determined independently from both cDNA and genomic clones are shown. Arrows indicate the locations of 5 ' ends mapped by S1 protection (sites at nucleotides 682 and 697 are most prevalent; sites at 658,669 , and 729 are less abundant in the mRNA population). A potential TATA-like sequence (near nucleotide 570) that does not appear to be used for directing initiation is enclosed by a small box, and triangles indicate the location of potential dibasic amino acid processing sites. The polyadenylation signal is indicated $(p A)$. The sequence of the introns was not determined completely; undetermined regions are indicated by $X$ 's. The string of $A$ 's shown (nucleotides 1784-1800) are added to the mRNA during processing and are not present in genomic DNA sequences.

water), dried, exposed for $4-7 \mathrm{~d}$ at $4^{\circ} \mathrm{C}$, and developed. After developing, the slides were stained through the emulsion with thionin or hematoxylin-eosin (gut tissue) for microscopic analysis.

\section{Results}

Isolation and structural analysis of $C D N A$ and genomic clones for rat preproNMB and comparison to rat preproGRP

A 180 base pair segment of the human preproNMB gene was amplified from human genomic DNA template, using the polymerase chain reaction and gene-specific primers based on the nucleotide sequence of a human prcproNMB cDNA (Krane et al., 1988). This fragment was used as a probe for screening a rat genomic library, allowing the isolation of 9 genomic bacteriophage clones. A 350 base Pst I-Pst I fragment in the genomic clones which hybridized specifically with the probe was subcloned and sequenced. Nucleotide sequence analysis of this genomic fragment showed an open reading frame beginning with an initiator methionine codon which encoded the first 28 amino acids of rat NMB, matching the corresponding region of the long form of the porcine NMB peptide (Minamino et al., 1985) in 25 of 28 positions and confirming its identity as the $5^{\prime}$ end of the rat preproNMB gene. A synthetic oligonucleotide primer was synthesized from $S^{\prime}$ untranslated sequences predicted from sequence analysis of the genomic fragment. Sequences in the rat
preproNMB cDNA template between this gene-specific primer in the $5^{\prime}$ untranslated region of preproNMB mRNA and the polyadenylated $3^{\prime}$ end were amplified using a previously described polymerase chain-reaction amplification technique (Frohman et al., 1988). The amplified cDNA fragment was subcloned, and used to locate 2 additional exons (exons 2 and 3 ) in the genomic clone by hybridization. All 3 exons of the genomic clone, adjacent $5^{\prime}$ flanking sequences, and the 650 base pair cDNA clone were sequenced. The results are shown in Figure 2 (no discrepancies were noted between the genomic clone and cDNA sequence).

A single open reading frame encoding a 117 amino acid precursor was identified in the cDNA sequence, beginning with an initiator methionine codon at position 767 surrounded by consensus sequences usually found at eukaryotic translation initiation codons (Kozak, 1984). The open reading frame encodes a 24 amino acid hydrophobic signal sequence immediately followed by the 32 amino acid rat NMB peptide. The amino acid sequence predicted for NMB is highly conserved in pig, human, and rat, showing only 4 amino acid differences among the 3 species (Fig. 1). In particular, the 3 mammalian NMB peptides are identical over the amidated carboxy terminal domain critical for biological activity of the bombesin peptide family (Broccardo et al., 1975; Erspamer et al., 1988). The NMB peptide 
Figure 3. S1 nuclease protection assay to map the $5^{\prime}$ ends of mRNAs from the rat preproNMB gene. The left-hand panel shows a chain-termination sequencing ladder $(C, T, A$, and $G$ positions in the template) used to precisely locate the $5^{\prime}$ ends, and the right-hand panel shows protected species corresponding to mRNAs with 5' ends near nucleotides 682 and 697 (Fig. 2). These 2 protected species are only seen after hybridization to rat brain mRNA $(B$, right panel) and are not observed after hybridization to rat duodenal $(D)$ or rat fibroblast $(F)$ mRNA which have undetectable levels of NMB mRNA on RNA blots. The yeast tRNA $(Y)$ hybridization serves as an additional negative control for specificity. Below the panels is a schematic diagram of the experiment, showing the location of the exon 1 sequences and the Eco RI site in the $5^{\prime}$ flanking genomic sequences used to truncate the probe (wavy line). The cluster of S1-protected species is shown below the diagram, with numbered solid arrows indicating the 2 prominent 5 ' ends and numbered dashed arrows showing species that are observed only after long exposures of the autoradiogram. The numbers adjacent to the 5 arrows indicate the position of the $5^{\prime}$ ends in the nucleotide sequence (Fig. 2).
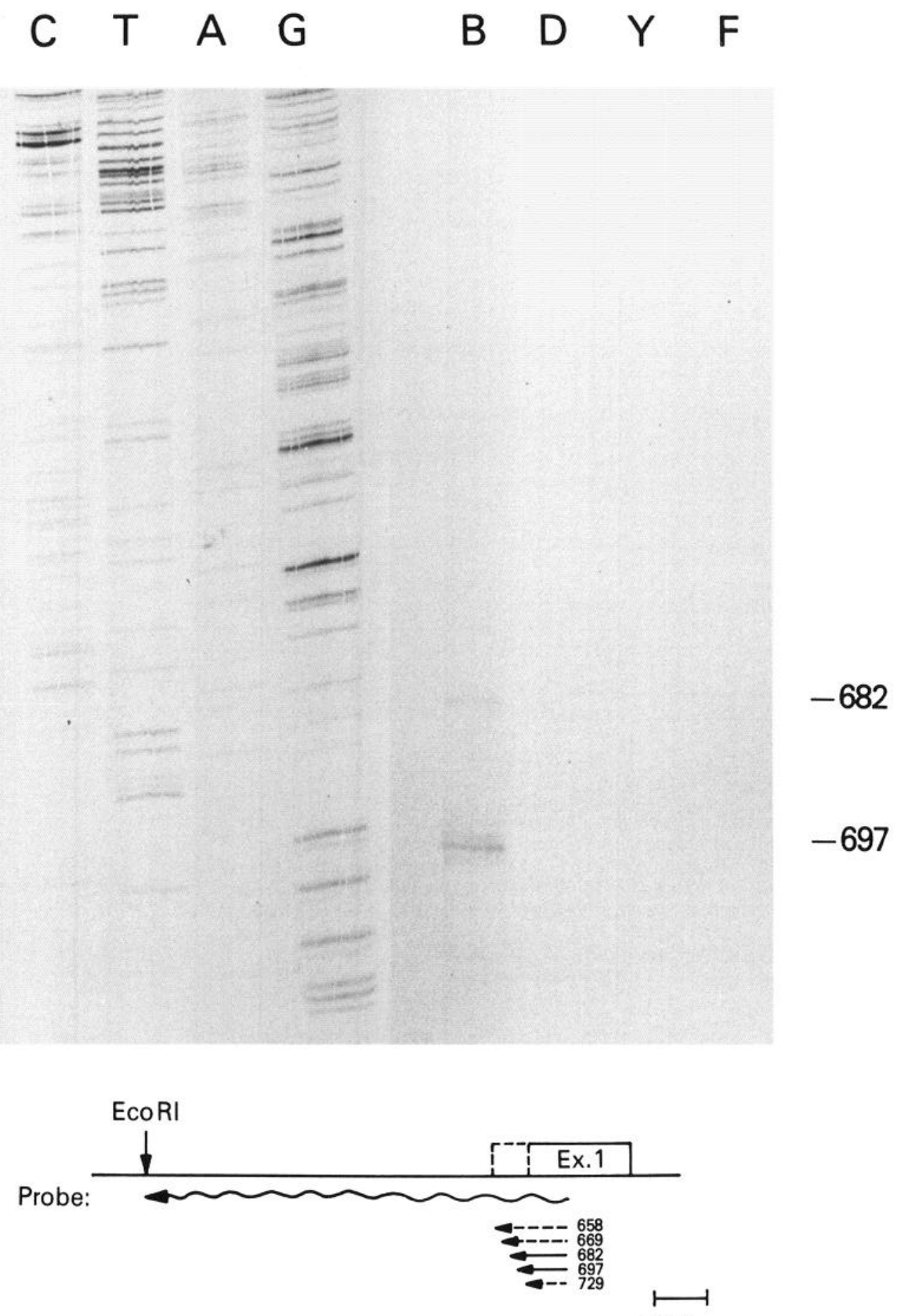

$100 \mathrm{bp}$ coding domain is followed by a glycine $\alpha$-amidation donor and a dibasic (Lys-Lys) cleavage recognition site (Loh et al., 1984), which presumably separates the NMB peptide from a 52 amino acid extension peptide (Fig. 2, underlined peptide) during posttranslational processing steps required to generate the mature amidated NMB peptide. Of interest, this 52 amino acid extension peptide is flanked on its carboxy end by another pair of basic amino acids (Arg-Arg) which may also serve as a cleavage recognition site for posttranslational processing of the extension peptide (Loh et al., 1984).
Comparison between the cDNA and genomic sequences reveals that the rat NMB gene is divided into 3 exons. The first intron divides a glycine codon located 4 residues upstream from the amidated carboxy terminal methionine residue of NMB. The first intron divides the GRP peptide coding domain of both the human (Spindel et al., 1987) and rat (Lebacq-Verheyden et al., 1988) genes at the same location, consistent with the hypothesis that the preproGRP and preproNMB genes diverged from a common ancestral precursor gene. In contrast to the conserved location of the first intron, there is very little nu- 

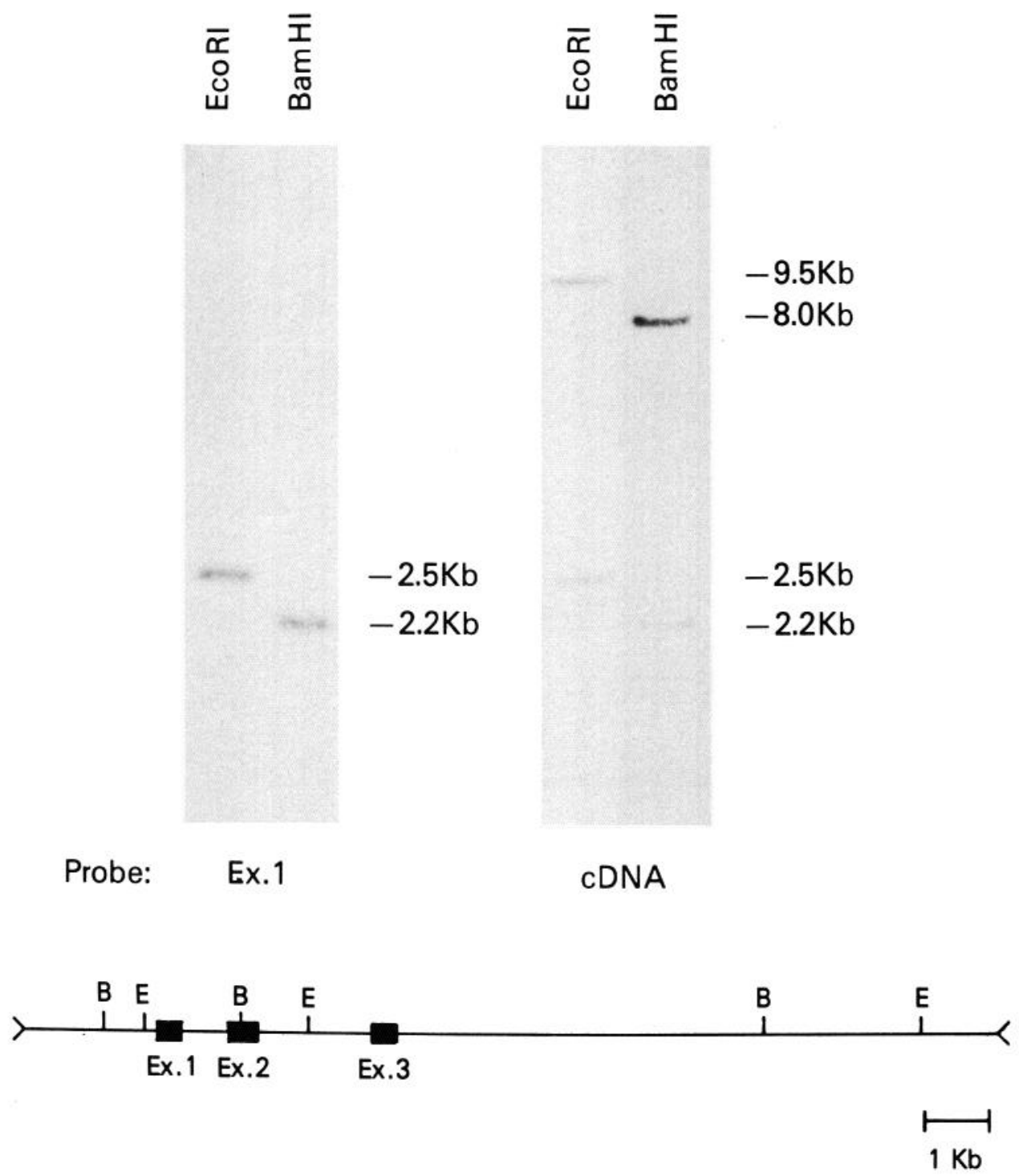

Figure 4. DNA blot analysis of rat genomic DNA. Rat genomic DNA was digested to completion with either Eco RI or Bam HI, followed by electrophoretic resolution of the fragments and blot transfer. Filters were hybridized with either an exon 1 probe from the genomic clone (left panel) or a near-fulllength cDNA probe (right panel). The lengths of hybridizing fragments are indicated on the right side of each panel. Below the panels is a schematic showing the structure of the gene as found in both genomic DNA and genomic clones, with the positions of Bam $\mathrm{HI}(B)$ and Eco RI $(E)$ sites indicated. cleotide sequence similarity between the rat preproGRP and preproNMB genes except in the short region encoding the amidated carboxy terminus of NMB and GRP critical for activity and specific binding to bombesin receptors.

Potential 5' termini of the rat preproNMB gene were mapped by $\mathrm{S} 1$ nuclease protection, as shown in Figure 3. The precise location of 5 ' ends was determined by comparing the mobilities of S1 protected probe fragments with chain-termination sequencing samples from the same single-stranded $\mathrm{m} 13$ subclone template and synthetic oligonucleotide primer used to synthesize the probe. The $5^{\prime}$ end of the mRNA is therefore defined by the comigrating chain-terminated species in the sequencing ladder. Short exposures of the S1 protection experiments (Fig. 3) show 2 S1-protected species corresponding to one predominant $5^{\prime}$ terminus at nucleotide 697 and a somewhat less abundant terminus at nucleotide 682 in the sequence (Fig. 2). Longer exposures show additional heterogeneity, with 3 additional $5^{\prime}$ ends mapping to nucleotides 658,669 , and 729 (data not shown). As expected, no specific S1-protected species are seen after hybridization to either Rat-1 fibroblast, duodenum, or yeast tRNA samples. All of the negative samples in the S1 nuclease protection assay have undetectable levels of mRNA by blot analysis (data not shown), although a few cells expressing moderate levels of NMB mRNA were identified in the duodenum by in situ hybridization.

Blot hybridization experiments performed on rat genomic DNA using cloned NMB gene fragments as probes shows a simple pattern of hybridizing fragments predicted from the restriction maps of the isolated genomic clones (Fig. 4, bottom). The 350 base Pst I-Pst I fragment containing exon 1 sequences hybridizes to a single $2.5 \mathrm{~kb}$ Eco RI and $2.2 \mathrm{~kb}$ Bam HI fragment in rat genomic DNA, as well as in isolated library clones. A cDNA probe containing sequences from all 3 exons hybridizes to the same Eco RI and Bam HI fragments and an additional $9.5 \mathrm{~kb}$ Eco RI fragment and $8.0 \mathrm{~kb}$ Bam HI fragment which contain the remaining sequences of the rat preproNMB gene in isolated clones (Fig. 4). These results are consistent with the existence of a single preproNMB gene in rat genomic DNA.

\section{Rat NMB and GRP MRNAs are distributed differently in the} rat nervous system

The tissue-specific distribution of the rat preproNMB gene was investigated using equivalent amounts $(10 \mu \mathrm{g})$ of oligo dT-selected mRNA isolated from a variety of rat tissues (Fig. 5). An 


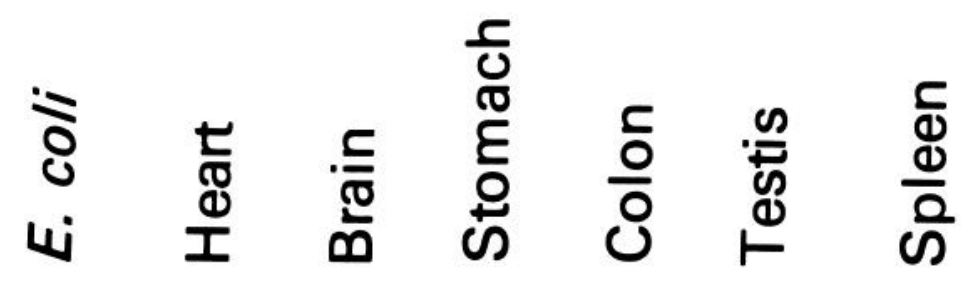

\section{$0.8 \mathrm{~Kb}-$}

Figure 5. RNA blot analysis of mRNA samples isolated from rat tissues. Ten micrograms of poly A+ RNA from rat brain, heart, stomach, colon, testis, and spleen were resolved on formaldehyde agarose gels, transferred to nitrocellulose, and hybridized with a NMB probe. $E$. coli RNA was included both as a negative control and to provide molecular size markers [ $16 \mathrm{~S}(1.6 \mathrm{~kb})$ and 23 $\mathrm{S}(2.9 \mathrm{~kb}) \mathrm{rRNAs}]$. A single $0.8 \mathrm{~kb}$ species is seen only in the mRNA isolated from brain, indicating that NMB mRNA is most abundant in the brain sample. Control hybridization with a $\beta$-actin probe establishes that the mRNA is intact in all tissue RNA samples (not shown).

\section{Probe: Ex.1 NMB}

exon 1 preproNMB-specific probe identifies a single 800 base mRNA species, which is more prevalent in brain than in other tissues examined. On longer exposures, a faint signal is observed in mRNA isolated from rat stomach. The other tissues contain undetectable levels of preproNMB mRNA. Northern blot studies on total RNA from dissected regions of the nervous system showed much higher levels of NMB mRNA in olfactory bulb and dorsal root ganglia than observed in total brain RNA (data not shown). The 800 base length of the single mRNA species observed is consistent with the gene structure determined from cDNA and genomic clones (Fig. 2) after posttranscriptional processing and polyadenylation.

In situ hybridization histochemistry using ${ }^{35} \mathrm{~S}$-labeled cRNA probes was performed to determine the precise distribution of
preproNMB-expressing cells in the rat brain. Serial sections were analyzed with a rat preproNMB antisense cRNA probe, a previously characterized rat preproGRP antisense cRNA probe (Zoeller et al., 1989), a sense rat NMB RNA probe (negative control), and thionin staining without hybridization (for optimal morphology) to allow direct comparison of the distribution of preproNMB and preproGRP mRNAs. An overview of the regional distribution of expression was obtained from autoradiographic films placed over coronal sections of rat brain (representative sections shown in Fig. 6). Two different preproNMB cRNA probes (containing either exon 1 sequences alone or fulllength cDNA sequences) were used; these showed identical patterns of distribution. No hybridization over background was seen in adjacent sections hybridized with the sense preproNMB 
NMB

A

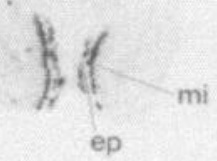

B



E


BM

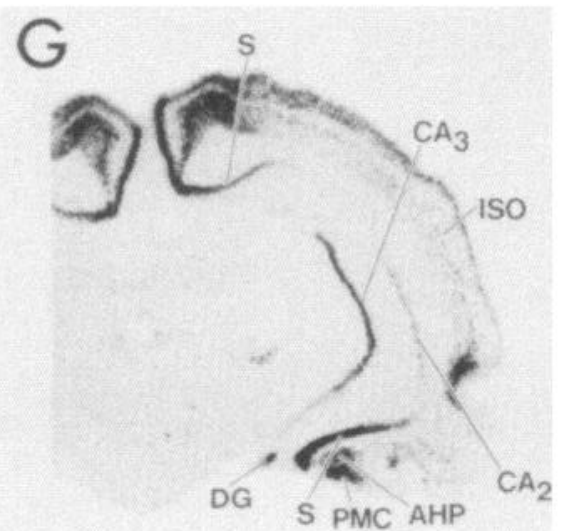

H

PB

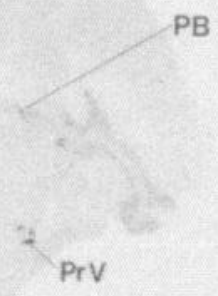

GRP

The Journa of Neuroscience, September 1990,1019$) 2923$

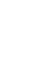

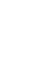


A

Figure 7. Coronal sections through the rat olfactory region $(A)$ and midbrain $(B)$ which were hybridized to an NMB sense cRNA probe, showing no specific hybridizing regions. $\times 4.5$.

probe (Fig. 7). The serial sections were dipped in emulsion and examined microscopically, and the intensity of hybridization of each probe to various regions of the nervous system was estimated using both autoradiographic films and microscopic analysis for detailed localization. Representative photomicrographs are shown in Figures 8-10, with a summary of all the data compiled in Table 1.

In the forebrain, a strong hybridization signal for preproNMB mRNA was observed in the main olfactory bulb-mitral cell layer and external plexiform layer (Figs. $6, A, 8$ ), and the poly-
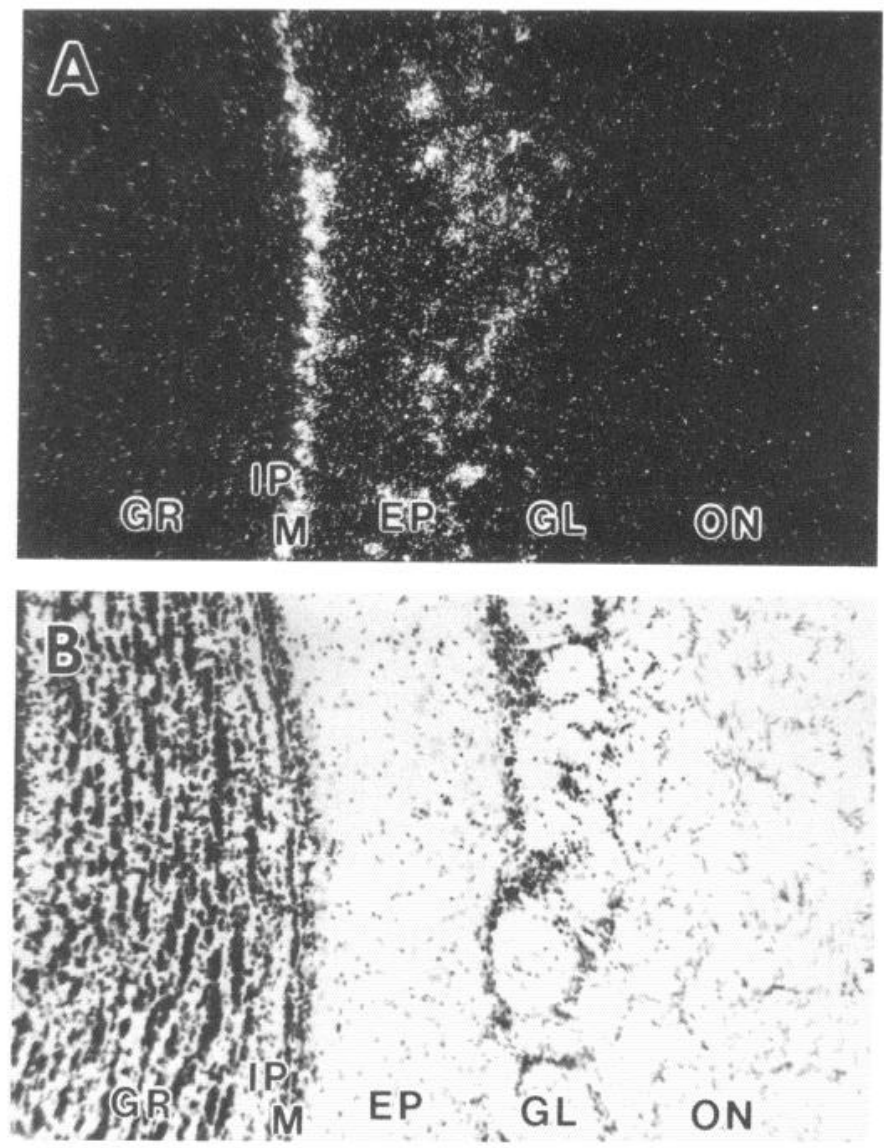

Figure 8. Dark-field $(A)$ and bright-field $(B)$ photomicrographs of sections from the olfactory bulb hybridized with the NMB antisense cRNA probe. $\times 77$. Abbreviations: $E P$, external plexiform layer; $G L$, periglomerular layer; $G R$, granular layer; $I P$, internal plexiform layer; $M$, mitral cell layer; $O N$, olfactory nerve layer. morph layer of the dentate gyrus (Fig. 6, $B, C$ ). Interestingly, the signal in the external plexiform layer of the main olfactory bulb was present only in the outer half of this layer (Fig. 8). Moderate hybridization signals were seen in the accessory olfactory bulb (mitral cell layer), pyramidal cell layer of Ammon's horn field CA3 (Fig. 6,B, C), and the central nucleus of the amygdala (Fig. $6 B)$. NMB mRNA was expressed moderately in an undescribed region between the anterior hypothalamic region and the septum (between the fornix and the median preoptic nucleus in plates 19 and 20, and between the fornix and triangular septal nucleus in plate 21; see Paxinos and Watson, 1986). Weaker signals were seen in the dorsal lateral subnucleus of the bed nucleus of the stria terminalis (Moga et al., 1989), the shell part of the nucleus accumbens (Paxinos and Watson, 1986), lateral habenular nucleus (Fig. 6B), arcuate nucleus, medial preoptic nucleus, and supramammillary nucleus. In contrast to NMB mRNA, GRP mRNA was much more widely distributed and generally more abundant in rat forebrain (Fig. 6, Table 1), consistent with the observations of previous studies (Zoeller et al., 1989). In the forebrain, GRP mRNA is abundantly expressed in the presubiculum (layer IV) (Fig. 6H), parasubiculum (layer II) (Fig. 6H), and pyramidal cell layer of the subiculum (Fig. $6 G$ ). In addition, a strong hybridization signal was observed in the granular cell layer of the ventral but not the dorsal part of dentate gyrus (Fig. $6 G)$, and the posterior part of the cortical amygdaloid nucleus (Fig. $6 G$ ). In the cortex, moderate hybridization signals were seen in layers II and III, and a weak hybridization signal was seen in deep layers (V and VI) (Fig. 6). It is interesting to note that in the allocortex, the most prominent signals were observed in cingulate and perirhinal cortex (Fig. 6,F, $G$ ). Moderate hybridization signals were detected in the anterior olfactory nucleus (Fig. 6E), medial entorhinal area (layer II) (Fig. $6 H$ ), presubiculum (layer II) (Fig. $6 H$ ), pyramidal layers of Ammon's horn fields CA2 and CA3 (Fig. $6 F, G$ ), medial nucleus of the amygdala, amygdalohippocampal area, lateral nucleus of the amygdala, basomedial nucleus of the amygdala, medial geniculate nucleus, suprachiasmatic nucleus, and the medial preoptic nucleus. Weaker signals were seen in the tenia tecta, lateral entorhinal area (layer II), pyramidal layer of Ammon's horn field CA1, anterior amygdaloid area, basolateral nucleus of the amygdala, medial septal nucleus, nucleus of the diagonal band, magnocellular preoptic nucleus, posterior intralaminar nucleus, median preoptic nucleus, anteroventral periventricular nucleus, paraventricular nucleus, and posterior hypothalamic area.

In the brain stem, moderate hybridization signals for NMB mRNA were seen in the principal sensory nucleus of the trigeminal (Fig. 6D), dorsal motor nucleus of the vagus (Fig. 9A, 
$B)$, posterior part of the peridorsal tegmental nucleus, nucleus incertus, and the hindbrain raphe (Fig. 6D). A discrete population of moderately hybridizing cells was detected in the ventral aspect of the medial part of the nucleus of the solitary tract, lateral to the rostral portion of the dorsal motor nucleus of the vagus. Weaker signals were observed in the nucleus of the trapezoid body, nucleus of the lateral lemniscus, dorsal part of the area postrema (Fig. 9A,B), lateral part of the parabrachial nucleus (Fig. $6 D$ ), lateral part of the facial nucleus, median raphe, gigantocellular reticular field, and the lateral reticular nucleus. Using the GRP probe, a moderate hybridization signal was observed in the inferior colliculus (external and dorsal regions) (Fig. $6 H$ ), medial part of the nucleus of the solitary tract (Fig. $9 C$ ), and the parabrachial nucleus (central lateral, dorsal lateral, and internal lateral) (Fig. 6H). Less intense hybridization was observed in the dorsal column nuclei, spinal trigeminal nucleus, central gray region, locus coeruleus, interfascicular nucleus, paranigral nucleus, and rostroventrolateral reticular nucleus. In the spinal cord, a moderate hybridization signal was observed in the substantia gelatinosa using the GRP probe.

In the PNS, a strong hybridization signal for the preproNMB cRNA probe was observed over a subset of cells in the trigeminal and dorsal root ganglia (Fig. 10A,B). In contrast, no cells hybridizing to the GRP probe were seen in dorsal root ganglia, where the NMB signal was intense (Fig. 10C). Infrequent hybridization signals were seen in the ganglion cell layer of the retina with the GRP, but not with the NMB probe.

\section{GRP and NMB expression in other tissues}

Moderate expression of both GRP and NMB mRNA was observed only in a few isolated cells of the gastrointestinal tract, explaining the absence of detectable mRNA by Northern blot analysis (Fig. 5). The hybridizing cells seen are mostly found in the subglandular region of the lamina propria, with a few positive cells observed in lymphatic ducts (data not shown). It is interesting to note that GRP immunoreactivity has recently been reported in alcohol extracts of bovine mesenteric lymphatic vessels (Foy et al., 1989), consistent with the identification of cells in these vessels expressing GRP and NMB mRNA. Further characterization will be needed for unambiguous identification of the cell type expressing GRP and NMB mRNAs. No hybridization signal for either NMB mRNA or GRP mRNA was observed in sections from the pituitary, liver, and kidney.

\section{Discussion}

In this study, we determined the complete structure and nucleotide sequence of the rat preproNMB gene from analysis of cDNA and genomic clones. The gene has 3 exons, and a heterogeneous $5^{\prime}$ end, with the first intron interrupting a glycine codon 4 residues upstream from the amidated carboxyl terminus of the NMB peptide. These structural features are similar to those observed previously for the rat preproGRP gene, consistent with the idea that both genes diverged from a common ancestral founder gene for the bombesin family of peptides. When the 2 genes are compared at the nucleotide sequence level, however, there is no sequence similarity in either the promoter or coding regions, with the exception of the 21 base region encoding the carboxyl terminal 7 amino acids of the GRP and NMB peptides ( $71 \%$ identity) which functionally and structurally define the group of bombesin-like peptides (Fig. 1). Thus, at the nucleotide sequence level, the genes are structurally quite
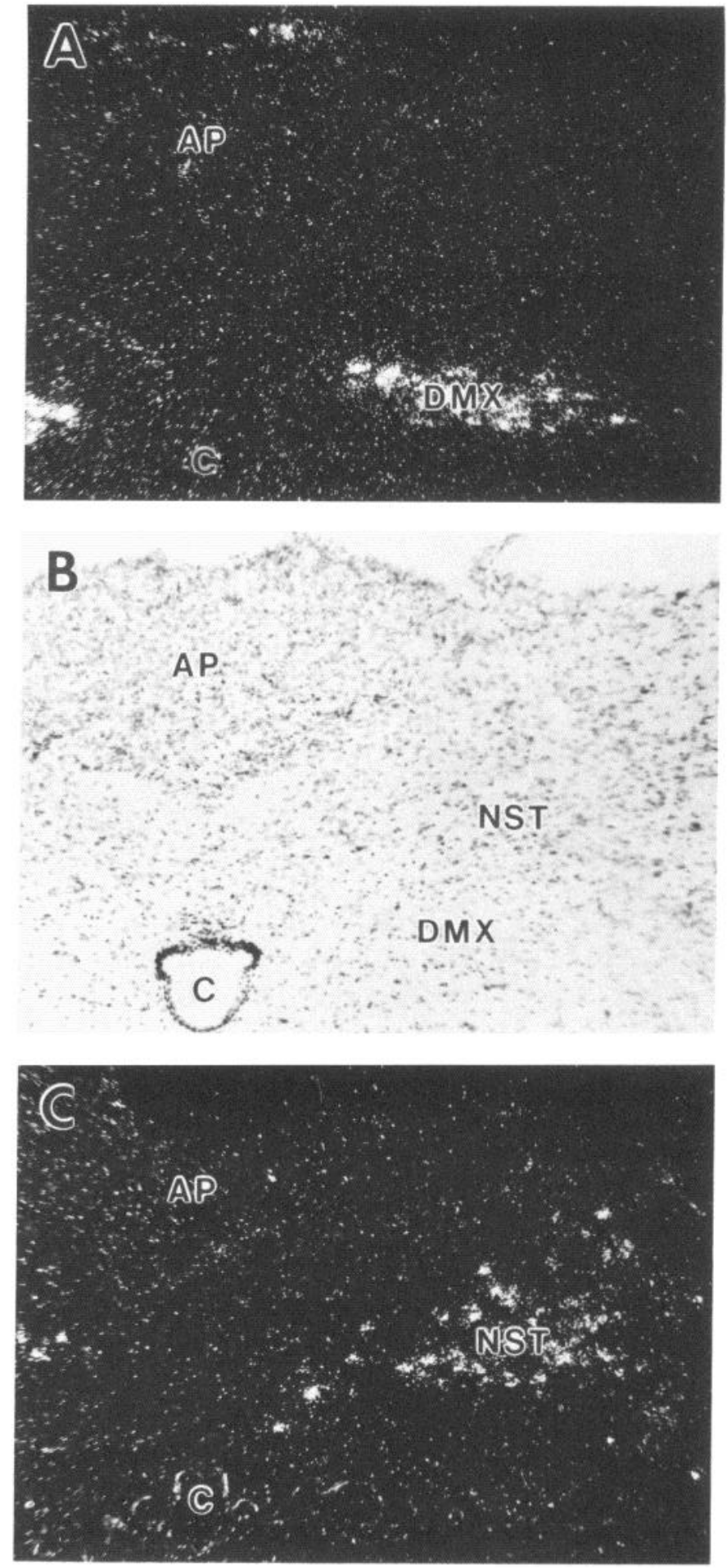

Figure 9. Dark-field $(A)$ and bright-field $(B)$ photomicrographs of the same section from the dorsal vagal complex and area postrema hybridized with the NMB antisense cRNA probe. A dark-field photomicrograph $(C)$ of the section adjacent to section $A$ or $B$ is shown after hybridization to the GRP antisense cRNA probe. $\times 77$. Abbreviations: $A P$, area postrema; $C$, central canal; $D M X$, dorsal motor nucleus of the vagus; $N S T$, nucleus of the solitary tract.

distinct. The NMB prohormone encodes a 52 amino acid extension peptide, surrounded on both sides by pairs of basic amino acids that often serve as cleavage sites for posttranslational processing enzymes (Loh et al., 1984). Further studies 
Table 1. Distributions of NMB and GRP mRNAs in rat nervous system

Tissue

NMB

GRP

I. Forebrain

A. Isocortex

II, III

$\mathrm{V}, \mathrm{VI}$

B. Olfactory regions (1)

1. Main olfactory bulb periglomerular layer external plexiform layer mitral cell layer

2. Accessory olfactory bulb glomerular layer mitral cell layer

3. Anterior olfactory $n$.

4. Olfactory tubercle

5. Tenia tecta

C. Hippocampal formation

1. Entorhinal area (medial)

II

IV-VI

2. Entorhinal area (lateral)

II

IV-VI

3. Presubiculum

II

IV

V, VI

4. Parasubiculum

II

IV-VI

5. Subiculum, pyramidal layer

6. CAl, pyramidal layer

7. CA2, pyramidal layer

8. CA3, pyramidal layer

9. Dentate gyrus granular layer polymorph layer

D. Amygdala (2)

1. Medial $\mathrm{n}$.

2. Amygdalohippocampal area

3. Cortical n. posterior part

4. Anterior amygdaloid area

5. Central $\mathrm{n}$.

6. Lateral $n$.

7. Basolateral $\mathrm{n}$.

8. Basomedial $\mathbf{n}$.

E. Septum

1. Medial n

2. $N$. diagonal band

3. Bed n. stria terminalis (3) dorsal lateral subnucleus

F. Basal ganglia and related regions

1. N. accumbens, shell

2. Magnocellular preoptic n. (4)

3. Substantia innominata

4. Substantia nigra ${ }^{a}$ compact part

5. Ventral tegmental area ${ }^{a}$

$\begin{array}{ll}- & ++ \\ - & + \\ & \\ + & - \\ +++ & - \\ +++ & - \\ + & - \\ ++ & - \\ - & ++ \\ (+) & - \\ - & +\end{array}$

$\begin{array}{ll}- & ++ \\ - & + \\ - & + \\ - & (+)\end{array}$

$-$ $+2$

- $\quad+++$

- +

- +

$++\quad++$

$-\quad+++(\mathrm{v})$

$+++$

$\begin{array}{ll}- & ++\end{array}$

$\begin{array}{ll}- & ++\end{array}$

$-\quad+++$

- +

$++\quad-$

- +

- +

- +

-

- +

$+$

$+\quad-$

- +

$(+)$

$++$

$++\quad-$ 
Table 1. Continued

Tissue

NMB

GRP

G. Thalamus

1. Lateral habenula

2. Anteroventral $\mathrm{n}$.

dorsomedial, ventrolateral

3. Medial geniculate $\mathbf{n}$.

4. Posterior intralaminar $n$.

5. Reticular $\mathbf{n}$.

6. Zona incerta

$+$

$+$

$+\quad+$

- $\quad+$

(+) $\quad-$

H. Hypothalamus (5)

1. Median preoptic $n$.

2. Anteruventral periventricular $\mathrm{n}$.

3. Suprachiasmatic $n$.

4. Supraoptic $n$.

5. Paraventricular $n$. parvicellular part magnocellular part

Arcuate $\mathrm{n}$.

7. Medial preoptic $n$. lateral, medial part central part

$\begin{array}{ll}- & + \\ - & + \\ - & ++ \\ (+) & - \\ - & + \\ - & (+) \\ + & - \\ & ++ \\ + & + \\ (+) & (+) \\ - & (+) \\ + & +\end{array}$

II. Brain stem

8. Dorsomedial nucleus

9. Supramammillary $n$.

10. Posterior hypothalamic area

A. Sensory

1. Somatosensory

Principal sensory n. $\mathrm{V}$

Dorsal column $\mathrm{n}$.

Spinal trigeminal $\mathrm{n}$.

$++$

$(+)$

$(+)$

(t)

$+$

$+$

N. lateral lemniscus, ventral

Inferior colliculus

external, dorsal part

3. Visceral

N. solitary tract

medial part

lateral part

Area postrema

Parabrachial n. (6)

central lateral

dorsal lateral

external lateral

internal lateral

superior lateral

ventral lateral

Kölliker-Fuse $\mathrm{n}$.

B. Motor

1. Facial n. (VII)

2. Dorsal motor $n$. $X$
$+$



$++$

$+$

$(+)$

$(+)$ 


\begin{tabular}{|c|c|c|c|}
\hline Tissue & & NMB & GRP \\
\hline \multicolumn{4}{|c|}{ C. Reticular core (including central gray and raphe) } \\
\hline & 1. Central gray & - & + \\
\hline & 2. Peridorsal tegmental $n$. & $++(\mathrm{p})$ & $-(\mathrm{p})$ \\
\hline & 3. N. incertus $(7)$ & ++ & - \\
\hline & 4. Locus coeruleus & $(+)$ & + \\
\hline & 5. Interfascicular $\mathrm{n}$. & - & + \\
\hline & 6. Paranigral $\mathrm{n}$. & - & + \\
\hline & 7. Median raphe & + & - \\
\hline & 8. Pontine reticular $\mathrm{n}$. & $(+)$ & - \\
\hline & 9. Hindbrain raphe & ++ & $(+)$ \\
\hline & 10. Gigantocellular reticular field (8) & + & - \\
\hline & 11. Rostroventrolateral reticular $n$. & - & + \\
\hline & 12. Lateral reticular $n$. & + & - \\
\hline \multicolumn{4}{|c|}{ III. Spinal cord } \\
\hline & 1. Substantia gelatinosa & $(+)$ & ++ \\
\hline \multicolumn{4}{|c|}{ IV. Peripheral nervous system } \\
\hline & 1. Trigeminal ganglion & +++ & - \\
\hline & 2. Dorsal root ganglion & +++ & - \\
\hline
\end{tabular}

Distributions of NMB and GRP mRNAs in rat nervous system. The strength of hybridization signal is graded based on the grains per positive cell observed in dark- and bright-field micrographs: +++ , strongest signal; ++ , moderate signal; + , weak signal; $(+)$, very weak signal; - , no hybridzation signal. Abbreviations: $n$. , nucleus; $p$, posterior; $v$, ventral. When there is some confusion about the nomenclature, references to the original literature are given. 1 , Switzer et al., 1985; 2, Krettek and Price, 1978; 3, Moga et al., 1989; 4, Swanson et al., 1987; 5, Swanson, 1987; 6, Fulwiler and Saper, 1984; 7, Berman, 1968; 8, Andrezik et al., 1981.

a The substantia nigra and ventral tegmental area are brain-stem structures.

will be needed to determine if this extension peptide is processed in the predicted fashion from the rat NMB prohormone to generate an additional peptide ligand of functional importance.

The exon 1 domain of the NMB gene and a near full-length cDNA clone were used to generate $\mathrm{cRNA}$ probes for localization of NMB mRNA in the rat nervous system using in situ hybridization histochemistry. Previous studies using radioimmunoassay identified relatively high levels of NMB immunoreactivity in a number of dissected brain regions, including the anterior and intermediate lobes of the pituitary, the olfactory bulb, the hippocampus, the hypothalamus, and the cortex (Minamino et al., 1984; Namba et al., 1985a; Moody et al., 1986). Immunohistochemical studies using NMB-specific antisera provide more precise localization of NMB immunoreactivity in fibers found in the medial thalamus of the brain (Namba et al., 1985b), the spinal cord (laminae I and II of the dorsal horn, lamina X, and the intermediolateral columns) (Namba et al., 1985b), and thyrotrope cells of the pituitary (Steel et al., 1988). The regional distribution of ranatensin-like immunoreactivity detected in cell bodies in the brain by immunohistochemical techniques (Chronwall et al., 1985) is in very good agreement with the localization of NMB mRNA-expressing brain regions reported here. There are, however, several differences between the distribution of mRNA observed by in situ hybridization and immunologic detection of $\mathrm{NMB}$-like peptides previously reported in the rat nervous system. In the cortex, NMB immunoreactivity was detected by radioimmunoassay (Minamino et al., 1984), but no corresponding hybridization signal was observed in this study. This difference may reflect the presence of NMB immunoreactive peptides in fibers projecting into the cortex from other brain regions. In the pituitary, NMB immunoreactivity was detected by radioimmunoassay (Minamino et al., 1984) and localized to thyrotropes by immunocytochemistry in the anterior lobe and a few weakly staining fibers in the neural lobe (Steel et al., 1988), while no mRNA was detected in any cell type in this study. While the presence of fibers could be consistent with both the radioimmunoassay and the in situ hybridization results, the explanation for our inability to find NMB mRNA in the thyrotropes is not clear. Perhaps the sensitivity of the assay systems for detecting the peptides is greater than the sensitivity of mRNA detection using in situ hybridization. Alternatively, the antisera used in the immunocytochemical studies may be cross-reacting with another structurally related antigen. Further studies will be needed to clarify the explanation for this difference.

NMB peptides were initially purified from spinal cord (Minamino et al., 1983, 1985) and were subsequently identified immunohistochemically in fibers and terminals predominantly in laminae I and II of the dorsal horn (Namba et al., 1985b). It is interesting to note that neurons in the dorsal root ganglia show intense hybridization signals for NMB mRNA and are known to project to laminae I and II of the dorsal horn. In addition, rhizotomy abolished most of the bombesin-like immunorcactivity observed in the posterior horn, consistent with the idea that the abundant peptides with bombesin-like immunoreactivity localized in terminals and fibers of laminae I and II originate in small neurons located in dorsal root ganglia (Panula et al., 1982, 1983). In situ hybridization studies with GRP and NMB probes show strong signals for NMB mRNA and no detectable GRP mRNA in the dorsal root ganglia. Taken together, these studies suggest that the bombesin-like peptides previously identified in small neurons in the dorsal root ganglia (Panula et 

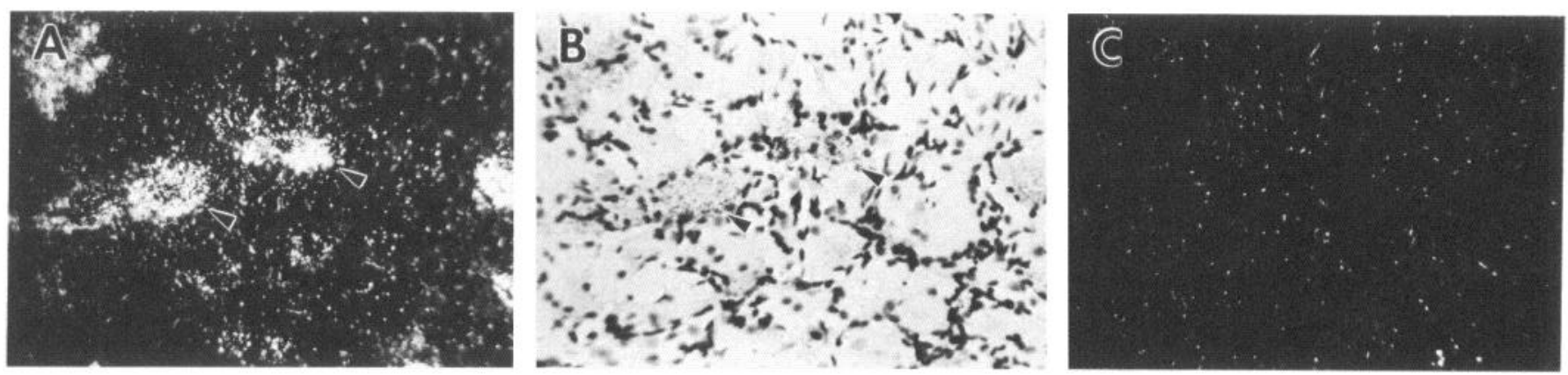

Figure 10. Dark-field $(A)$ and bright-field $(B)$ photomicrographs of the same section showing a strong hybridization signal $(+++$, Table 1$)$ to scattered cell bodies in the dorsal root ganglion with the NMB probe. A dark-field photomicrograph $(C)$ shows only background hybridization signal (-, Table 1) in dorsal root ganglion with a GRP probe. The arrows indicate labeled cells in the ganglion. $\times 150$.

al., 1983) and axonally transported to the dorsal horn of the spinal cord (Panula et al., 1982), often designated as GRP in the literature (Panula et al., 1983; Panula, 1986; Ruda et al., 1986), appear to actually derive from the NMB rather than the GRP gene.

Mammalian bombesin-like peptides have a wide spectrum of effects, including a variety of pharmacological actions in the rat brain. With the administration of GRP or bombesin into rat brain, hypothermia (Brown et al., 1977a), hyperglycemia (Brown et al., 1977b, 1979), compulsive grooming (Brown et al., 1977a), anorexia (Gibbs et al., 1979), and other modifications of behavior and metabolism were noted (Taché and Brown, 1982). In addition, bombesin-like peptides are central neuroregulators of gastrointestinal motility (Porreca and Burks, 1983), gastric acid secretion (Taché et al., 1980), and secretion of a variety of hormones from the stomach, intestine, pancreas, adrenals, and pituitary (Taché et al., 1979; McDonald et al., 1983).

The bioactivities associated with bombesin-like peptides appear to be mediated by high-affinity binding to cell surface bombesin receptors located on responding cells. In brain, both GRP and NMB can bind at high affinities to identified binding sites (Moody et al., 1986). Bombesin binding sites have been mapped by autoradiography to a number of rat brain regions, including the olfactory bulb, nucleus accumbens, periventricular nucleus, central nucleus of the amygdala, suprachiasmatic nucleus, dentate gyrus, subiculum, nucleus of the solitary tract, and substantia gelatinosa (Wolf et al., 1983; Zarbin et al., 1985). Interestingly, all of these regions coincide with regions that contain either GRP or NMB mRNA. It will be of great interest in the future to determine whether there are "bombesin" receptor subtypes in these brain regions which can distinguish between the related mammalian neuropeptides GRP and NMB. The striking differences in the brain regions expressing either GRP or NMB mRNAs seen in this comparative study strongly suggest that the 2 peptides may have distinct and separate physiologic functions as neuropeptides in the brain.

\section{References}

Anastasi A, Erspamer V, Bucci M (1971) Isolation and structure of bombesin and alytesin, two analogous active peptides from the skin of the European amphibians Bombina and Alytes. Experimentia 27: $166-167$

Andrezik J, Chan-Palay V, Palay SL (1981) The nucleus paragigantocellularis lateralis in the rat. Anat Embryol (Berl) 161:355-371.

Berman AL (1968) The brain stem of the cat. A cytoarchitectonic atlas with stereotaxic coordinates. Madison, WI: The University of Wisconsin Press.

Broccardo M, Erspamer G, Melchiorri P, Negri L, De Castiglione R
(1975) Relative potency of bombesin-like peptides. Br J Pharmacol 55:221-227.

Brown M, Rivier J, Vale W (1977a) Bombesin: potent effects on thermoregulation in the rat. Science 196:998-1000.

Brown M, Rivier J, Vale W (1977b) Bombesin affects the central nervous system to produce hyperglycemia in rats. Life Sci 21:17291734.

Brown M, Taché Y, Fischer D (1979) Central nervous system action of bombesin: mechanism to induce hyperglycemia. Endocrinology 105:660-665.

Chronwall B, Pisano J, Bishop J, Moody T, O'Donohue T (1985) Biochemical and histochemical characterization of ranatensin immunoreactive peptides in rat brain: lack of coexistence with bombesin/GRP. Brain Res 338:97-113.

Davis L, Dibner M, Battey J (1986) Basic methods in molecular biology. Amsterdam: Elsevier.

Erspamer G, Severini C, Erspamer V, Melchiorri P, Delle Fave G, Nakajima T (1988) Parallel bioassay of 27 bombesin-like peptides on nine smooth muscle preparations. Structure-activity relationships and bombesin receptor subtypes. Regulat Peptides 21:1-11.

Foy WL, Allen JM, McKillop JM, Goldsmith JP, Johnston CF, Buchanan KD (1989) Substance P and gastrin releasing peptide in bovine mesenteric lymphatic vessels: chemical characterization and action. Peptides 10:533-537.

Frohman MA, Dush MK, Martin GR (1988) Rapid production of full-length cDNAs from rare transcripts: amplification using a single gene-specific oligonucleotide primer. Proc Natl Acad Sci USA 85 : 8998-9002.

Fulwiler CE, Saper CB (1984) Subnuclear organization of the efferent connections of the parabrachial nucleus in rat brain. Brain Res Rev 7:229-259.

Gibbs J, Fauser D, Rowe E, Rolls B, Rolls E, Maddison S (1979) Bombesin suppresses feeding in rats. Nature 282:208-210.

Kozak M (1984) Compilation and analysis of sequences upstream from the translational start in eukaryotic mRNAs. Nucleic Acids Res 12:857-872.

Krane IM, Naylor SL, Helin-Davis D, Chin WW, Spindel ER (1988) Molecular cloning of cDNAs encoding the human bombesin-like peptide neuromedin B. J Biol Chem 263:13317-13323.

Krettek JE, Price JL (1978) A description of the amygdaloid complex in the rat and cat with observations on the intra-amygdaloid axonal connections. J Comp Neurol 178:255-280.

Lebacq-Verheyden AM, Krystal G, Sartor O, Way J, Battey J (1988) The rat prepro gastrin releasing peptide gene is transcribed from two initiation sites in the brain. Mol Endocrinol 2:556-563.

Lebacq-Verheyden AM, Way J, Battey J (1989) Structural characterization of a brain-specific promoter region directing transcription of the rat prepro gastrin releasing peptide gene. Mol Brain Res 7:235241.

Loh YP, Brownstein MJ, Gainer H (1984) Proteolysis in neuropeptide processing and other neural functions. Annu Rev Neurosci 7:189222.

McDonald TJ, Jornvall H, Nilsson G, Vagne M, Ghatei M, Bloom SR, Mutt V (1979) Characterization of a gastrin releasing peptide from porcine non-antral gastric tissue. Biochem Biophys Res Commun 90: 227-237. 
McDonald TJ, Ghatei MA, Bloom SR, Adrian TE, Mochizuki T, Yanaihara C, Yanaihara N (1983) Dose-response comparisons of canine plasma gastroenteropancreatic hormone responses to bombesin and the porcine gastrin-releasing peptide. Regulat Peptides 5:125-137.

Minamino N, Kangawa K, Matsuo H (1983) Neuromedin B: a novel bombesin-like peptide identified in porcine spinal cord. Biochem Biophys Res Commun 114:541-548.

Minamino N, Kangawa K, Matsuo H (1984) Neuromedin B is a major bombesin-like peptide in rat brain: regional distribution of neuromedin B and neuromedin C in rat brain, pituitary and spinal cord. Biochem Biophys Res Commun 124:925-932.

Minamino N, Sudoh T, Kangawa K, Matsuo H (1985) Neuromedin B-32 and B-30: two "big" neuromedin B identified in porcine brain and spinal cord. Biochem Biophys Res Commun 130:685-691.

Moga MM, Saper CB, Gray TS (1989) Bed nucleus of the stria terminalis: cytoarchitecture, immunohistochemistry, and projection to the parabrachial nucleus in the rat. J Comp Neurol 283:315-332.

Moody TW, Korman LY, O'Donohue TL (1986) Neuromedin B-like peptides in rat brain: biochemical characterization, mechanism of release and localization in synaptosomes. Peptides 7:815-820.

Mullis K, Faloona F, Scharf S, Saiki R, Horn G, Erlich H (1986) Specific enzymatic amplification of DNA in vitro: the polymerase chain reaction. Cold Spring Harbor Symp Quant Biol LI:263-273.

Namba M, Ghatei MA, Bishop AE, Gibson SJ, Mann DJ, Polak JM, Bloom SR (1985a) Presence of neuromedin B-like immunoreactivity in the brain and gut of rat and guinea-pig. Peptides 3:257-263.

Namba M, Ghatei M, Gibson S, Polak J, Bloom S (1985b) Distribution and localization of neuromedin B-like immunoreactivity in pig, cat and rat spinal cord. Neuroscience 15:1217-1226.

Panula $P$ (1986) Histochemistry and function of bombesin-like peptides. Med Biol 64:177-192.

Panula P, Yang H-Y, Costa E (1982) Neuronal location of the bombesin-like immunoreactivity in the central nervous system of the rat. Regulat Peptides 4:275-283.

Panula P, Hadjiconstantinou M, Yang H, Costa E (1983) Immunohistochemical localization of bombesin/gastrin-releasing peptide and substance $P$ in primary sensory neurons. J Neurosci 3:2021-2029.

Panula P, Yang H-Y, Costa E (1984) Comparative distribution of bombesin/GRP- and substance-P-like immunoreactivities in rat hypothalamus. J Comp Neurol 224:606-617.

Paxinos G, Watson C, eds (1986) The rat brain in stereotaxic coordinates, 2nd ed. Sydney: Academic.

Porreca F, Burks T (1983) Centrally administered bombesin affects gastric emptying and small and large bowel transit in the rat. Gastroenterology 85:313-317.

Roth K, Weber E, Barchas J (1982) Distribution of gastrin releasing peptide bombesin-like immunostaining in rat brain. Brain Res 251: 277-282.

Ruda MA, Bennett GJ, Dubner R (1986) Neurochemistry and neural circuitry in the dorsal horn. Prog Brain Res 66:219-268.

Sanger F, Nicklen S, Coulson AR (1977) DNA sequencing with chainterminating inhibitors. Proc Natl Acad Sci USA 74:5463-5467.
Spindel E (1986) Mammalian bombesin-like peptides. Trends Neurosci $9: 130-133$.

Spindel E, Zilberberg MD, Chin WW (1987) Analysis of the gene and multiple messenger ribonucleic acids (mRNAs) encoding human gastrin-releasing peptide: alternate RNA splicing occurs in neural and endocrine tissue. Mol Endocrinol 1:224-232.

Steel JH, Van Noorden S, Ballesta J, Gibson SJ, Ghatei MA, Burrin J, Leonhardt U, Domin J, Bloom SR, Polak J (1988) Localization of $7 B 2$, neuromedin $B$, and neuromedin $U$ in specific cell types of rat, mouse, and human pituitary, in rat hypothalamus, and in 30 human pituitary and extrapituitary tumors. Endocrinology 122:270-282.

Swanson, LW (1987) The hypothalamus. In: Handbook of chemical neuroanatomy, Vol 5, Integrated systems of the CNS (Hökfelt $T$, Björklund A, Swanson LW, eds), pp 1-24. Amsterdam: Elsevier.

Swanson LW, Köhler C, Björklund A (1987) The limbic region. I: the septohippocampal system. In: Handbook of chemical neuroanatomy, Vol 5, Integrated systems of the C.NS (Hökfelt T, Björklund A, Swanson LW, eds), pp 125-277. Amsterdam: Elsevier.

Switzer RC, deOlmos J, Heimer L (1985) Olfactory system. In: The rat nervous system (Paxinos G, ed), pp 1-36. Sydncy: Academic.

Taché Y, Brown M (1982) On the role of bombesin in homeostasis. Trends Neurosci 5:431-433.

Taché Y, Brown M, Collu R (1979) Effects of neuropeptides on adenohypophyseal hormone response to acute stress in male rats. Endocrinology 105:220-224.

Taché Y, Vale W, Rivier J, Brown M (1980) Brain regulation of gastric secretion: influences of neuropeptides. Proc Natl Acad Sci USA 77: 5515-5519.

Wada E, Wada K, Boulter J, Deneris E, Heinemann S, Patrick J, Swanson LW (1989) Distribution of alpha2, alpha3, alpha4, and beta2 neuronal nicotinic receptor subunit mRNAs in the central nervous system: a hybridization histochemical study in the rat. J Comp Neurol 284:314-335.

Westendorf JM, Schonbrunn A (1983) Characterization of bombesin receptors in a rat pituitary cell line. J Biol Chem 258:7527-7535.

Wolf SS, Moody TW, O'Donohue TL, Zarbin MA, Kuhar MJ (1983) Autoradiographic visualization of rat brain binding sites for bombesin-like peptides. Eur J Pharmacol 87:163-164.

Zachary I, Rozengurt E (1985) High-affinity receptors for peptides of the bombesin family in Swiss 3T3 cells. Proc Natl Acad Sci USA 82: 7616-7620.

Zachary I, Rozengurt E (1987) Identification of a receptor for peptides of the bombesin family in Swiss $3 \mathrm{~T} 3$ cells by affinity cross linking. $\mathrm{J}$ Biol Chem 262:3947-3950.

Zarbin MA, Kuhar MJ, O'Donohue TL, Wolf SS, Moody TW (1985) Autoradiographic localization of $\left.{ }^{(25} \mathrm{I}_{-} \mathrm{Tyr}^{4}\right)$ bombesin-binding sites in rat brain. J Neurosci 5:429-437.

Zocller RT, Lebacq-Verheyden AM, Battey J (1989) Distribution of two distinct messenger ribonucleic acids encoding gastrin-releasing peptide in rat brain. Peptides 10:415-422. 